Tract. Ed. Johnson, L.R. 1994; 2: 1139-1169

${ }^{25}$ Souza Brito ARM, Rodriguez JÁ, Hiruma-Lima CA, Haun M, Nunes DS. Antiulcerogenic activity of trans-dehydrocrotonin from Croton cajucara. Planta Medica. 1998; 64: 126-129

${ }^{26}$ Souza-Formigoni MLO, Oliveira MGM, Monteiro MG, SilveiraFilho NG, Braz S, Carlini EA. Journal of Ethnopharmacology. 1991; 34: 21-27

${ }^{27}$ Stephenson RP. A modification of receptor theory. Br. J. Pharmacol. 1956; 11:379-393

${ }^{28}$ Takeuchi K, Yagi K, Kato S, Uakawa H. Gastroenterology. 1997; 113: 1553-1559

${ }^{29}$ Van der Berg. Plantas medicinais da Amazônia - Contribuição ao seu conhecimento sistemático, Museu Paraense Emílio Goeldi. Belém. 1993; p. 223

${ }^{30}$ Vane JR. A sensitive method for the assay of 5-hydroxytryptamine. Br. J. Pharmacol. Chemother. 1957; 12: 344-349

${ }^{31}$ Vuyyuru L, Schubert ML. Histamine, acting via H3 receptors, inhibits somatostatin and stimulates acid secretion in isolated mouse stomach. Gastroenterology. 1997; 113: 1545-1552

${ }^{32}$ Weigert N, Schaffer K, Wegner U, Schusdziarra V, Classen M, Schepp W. Functional characterization of muscarinic receptor stimulating gastrin release from rabbit antral G-cells in primary culture. European Journal of Pharmacology. 1994; 264: 337-344

\section{Thermal behavior of biflorin by beans TG and a DSC photovisual system}

\author{
C. F. S. Aragão'; C. S. A. Lima²; E. L. C. Amorin²; T. M. Aquino²; \\ R. O. Macêdo ${ }^{1 *}$
}

'Laboratório de Tecnologia Farmacêutica, UFPB, Campus I, 59059-900, João Pessoa, PB, Brasil

${ }^{2}$ Departamento de Biofísica e Radiologia, CCB, Universidade Federal de Pernambuco, 50.670-901, Recife, PE

ruimacedo@ltf.ufpb.br

\begin{abstract}
This work proposes thermal characterization, of the biflorine, orto-quinon of Capraria biflora L., through the TG and DSC photovisual data. The thermogravimetric results showed that the decomposition reaction biflorine occurs three steps under air atmosphere, The DSC of biflorin presented five peaks relating to phase transitions. The DSC photovisual system demonstrated changes in biflorin.
\end{abstract}

Thermal behaviour studies in which thermal techniques are applied to naturally occurring substances are rather scarce in the literature ${ }^{1,5}$.

Biflorin, a orto-quinon, (Figure 1) is constituent of the root of Capraria biflora L. (Scrophulariaceae). This plant is popularly is known as "chá da terra", "chá da américa", "chá das antilhas" and "chá da calçada" a plant used extensively in Northeast Brazil as antibiotic in the treatment of infections for fungi, dhermatofilus, yeasts and bacterias ${ }^{6,10}$.

The present work deals with a thermal behavior of biflorin by means of TG and a DSC photovisual system.

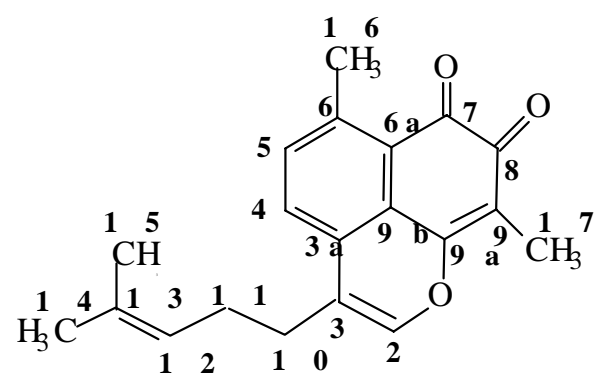

Figure 1.3-prenyl-6,9-dimetil-7,8-dioxoquinon (biflorin).

\section{Results and discussion}

The TG curves of the biflorine (Figure 2, curve 1) presents three thermal decomposition stages, with temperature 
intervals: $218.89-424.50{ }^{\circ} \mathrm{C}(15.51 \%), 375.52-529.36{ }^{\circ} \mathrm{C}(15.25 \%)$ and $530.29-687.28^{\circ} \mathrm{C}(62.95 \%)$, with mineral residue of $5.66 \%$.

The DSC curve of biflorine (Figure 2, curve 2) presented five peaks relating to phase transitions. The first and second peaks corresponds to endothermics process, and presented temperature peaks and reaction heat, respectively: $83.20^{\circ} \mathrm{C}$; $1.40 \mathrm{~J} / \mathrm{g}$ and $159.11^{\circ} \mathrm{C} ;-59.31 \mathrm{~J} / \mathrm{g}$. The third peak, exothermic, at $170.31^{\circ} \mathrm{C}(116.78 \mathrm{~J} / \mathrm{g})$. The three first peaks there are no mass loss (Figure 2, curves 1 and 2), which indicate that the first and third phase trasitons are related with changes in form of the biflorine molecule. The second peak is caracteristc of the melting point transition.

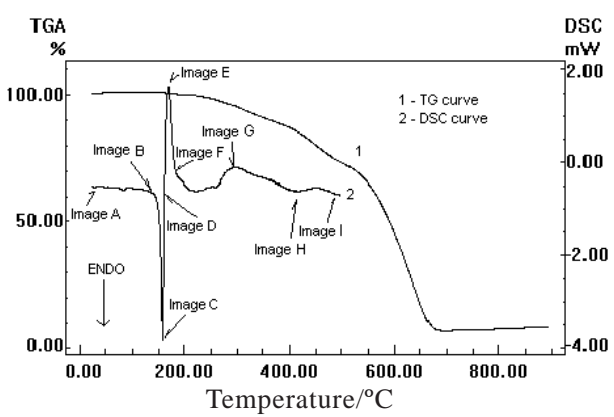

Figure 2. TG and DSC curves of biflorin

The picture from the photovisual system (Figure 3) showed changes in biflorine. This is verified in picture $\mathbf{A}$, which show the presence of biflorin crystal with dark-red color. Picture $\mathbf{B}$, at $140{ }^{\circ} \mathrm{C}$, at this temperature, there is no colour change in form of the biflorine molecule. Pictures $\mathbf{C}$ and $\mathbf{D}$, at 158 and 161 ${ }^{\circ} \mathrm{C}$ despits the melting point with darkness color. Pictures $\mathbf{E}$ and F, at 170 and $187^{\circ} \mathrm{C}$, reaveled dark substance with energetic transformations in the molecule. Pictures $\mathbf{G}$, at $200{ }^{\circ} \mathrm{C}$, indicate the initial decomposition of the biflorin, followed by decomposition with mass loss (Figure 3, Pictures H - I and Figure 2, TG and DSC curves).

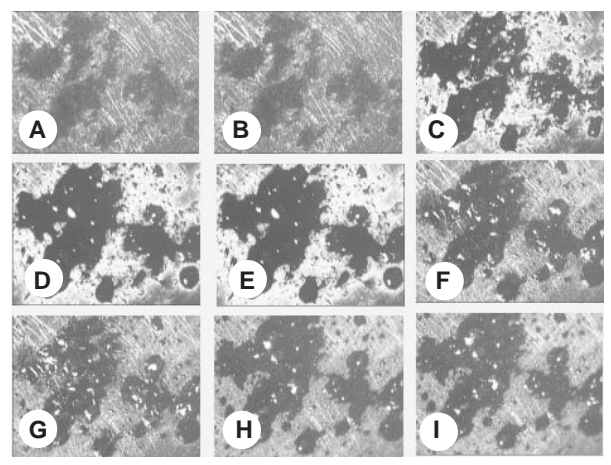

Figure 3. Images of DSC photovisual system from biflorine. Images were taken at $\mathbf{A}-25^{\circ} \mathrm{C}, \mathbf{B}-140^{\circ} \mathrm{C}, \mathbf{C}-158^{\circ} \mathrm{C}, \mathbf{D}-161^{\circ} \mathrm{C}$, $\mathbf{E}-170^{\circ} \mathrm{C}, \mathbf{F}-186^{\circ} \mathrm{C}, \mathbf{G}-200^{\circ} \mathrm{C}, \mathbf{H}-408^{\circ} \mathrm{C}$ and $\mathbf{I}-500{ }^{\circ} \mathrm{C}$. physico-chemical change (melting point, decomposition and transformation molecule).

\section{Material and Methods}

The TG curves of biflorine were obtained with a Shimadzu thermobalance, model TGA- $50 \mathrm{H}$, under a synthetic air $\left(20 \pm 0.5 \%\right.$ oxigen and $80 \pm 0.5 \%$ nitrogen) flow $20 \mathrm{ml} . \mathrm{min}^{-1}$, at heating rate $10{ }^{\circ} \mathrm{C} \cdot \mathrm{min}^{-1}$, up to temperature of $900{ }^{\circ} \mathrm{C}$. Sample mass about $4 \mathrm{mg}$ were packed in an alumina cell.

The DSC coupled to the photovisual system data were obtained in Shimadzu differential scanning calorimeter, model DSC-50, constituted for Olympus microscope connected to high resolution camera, model VCC-D520, Sanyo and image capture software. The temperature interval was of $25-500{ }^{\circ} \mathrm{C}$, using aluminum pan, heating rates of $10^{\circ} \mathrm{C} / \mathrm{min}$. The nitrogen flow was of $50 \mathrm{ml} / \mathrm{min}$. The sample amount was $2.00 \mathrm{mg}$. The TG and DSC curves were analyzed with TASYS software from Shimadzu. The DSC apparatus was calibrated by indium $\left(156.6{ }^{\circ} \mathrm{C} \pm 0.2\right)$ and zinc $\left(419.5^{\circ} \mathrm{C} \pm 0.3\right)$ standards melting point. The heat flow and enthalpy were calibrated by indium heat of fusion $(28.58 \mathrm{~J} /$ $\mathrm{g} \pm 0.3$ ) using the same conditions of samples.

\section{Acknowledgements}

The autors thank ANVISA/MS, CAPES and CNPq for financial support.

\section{References}

${ }^{1}$ Macêdo R O. An. Assoc. Bras. Quim., 47(4) (1998) 313-315.

${ }^{2}$ Aragão C F S, Macêdo R O, Do-Nascimento T G \& Macêdo A M C J. Therm. Anal. Cal., 56(1999) 1323-1327

${ }^{3}$ Macêdo R O, Aragão C F S, Do-Nascimento T G \& Gomes A P B J Therm. Anal. Cal., 59 (2000) 657-661

${ }^{4}$ Aragão C F S, Macêdo R O \& Barbosa-Filho J M J Therm. Anal. Cal., 64 (2001) 185-191

${ }^{5}$ Macêdo R O, Aragão C F S, Do-Nascimento T G \& Medeiros A C D. Revista Brasileira de Alimentos, 06(jan/jun) (1998) 5-11

${ }^{6}$ Gonçalves de Lima O, D’ Albuquerque I L, Loureiro P, Carmona C L \& Bernard M Z Rev. Quím. Indust., 14, 2-3 (1953)

${ }^{7}$ Gonçalves de Lima O, D'Albuquerque I L \& Navarro M C P. Rev. Inst. Antibiot. (1/2), 79-81 (1962)

${ }^{8}$ Comin J, Gonçalves de Lima O, Grant H N, Jackman L N, KellerSchierlein W. Prelog V. Helv. Chim. Acta, 46, 409 (1963)

${ }^{9}$ Lyra Jr D P. Aquino T M, Neves C S, Lima C S A, Gusmão N B, Wanderley A G \& Santana D P Rev. Farm. Quim. 32, 1, 19-23 (1999)

${ }^{10}$ Lyra Jr D P, Aquino T M, Neves C S, Lima C S A, Amorim E L C, Wanderley A G \& Santana D P Boll. Chim. Pharmacist. 138, 2,309(1999)

The photovisual system allowed visualization of a 